\title{
APPENDIX FOUR
}

\section{DID THE GREEKS BELIEVE IN THEIR GODS?}

\section{In Capter VI I ventured the question:}

Did (the) Syracusans believe in the divinity of their rulers? Did (the) Athenians in their 'theopoetics,' such as most exemplarily those concerning Demetrios? And what about other Greek cities? And what about Menekrates' deification?

This question brings us dangerously close to a vexing and in my view sorely misguided recent campaign against the legitimacy of using the terms 'belief/believe' in the study of Greek religion. I preferred to reserve a discussion of this phenomenon for the present Appendix.

According to its champions our modern notion 'belief' did not and could not 'exist' in Greek (or any other traditional non-Christian) religion. Curiously enough, this modish tenet-"something of an orthodoxy in the treatment of Greek religion"1-does not seem to owe its direct inspiration to earlier studies in the fields of religious studies and anthropology, where a similar discussion developed in the sixties and seventies of the last century. Among the protagonists Needham is the only regular guest in current studies in Greek 'belief'. ${ }^{2}$ His two main arguments, to which we will return later, are, first, that the term is intrinsically Western and Christian and cannot be translated into the languages of a majority of other cultures, and, second, that the wide range of definitions and lack of a consistent meaning in Western thought makes the term useless for analysis. Others joined his scepticism, as W.C. Smith had already done some years before in his influential book of $1977 .{ }^{3}$ In the fields of anthropology and theology, however,

${ }^{1}$ Harrison 2000, 18.

${ }^{2}$ Needham 1972, 14-39; 64-135. Giordano-Zecharya 2005, refers also to J. Pouillon, Remarques sur le verbe 'croire', in: M. Izard \& P. Smith (edd.), La fonction symbolique (Paris 1979) 43-51.

3 W.C. Smith, Belief and History (Charlottesville VA 1977). Other pioneers include: R. Bellah, Beyond Belief: Essays on Religion in a Post-Traditional World (New York 1970); G. Luckman, Belief, Unbelief, and Religion, in: R. Caporale \& A. Grumelli (edd.), The Culture of Unbelief: Studies and Proceedings from the First International Symposium on Belief Held at Rome 1969 (Berkeley etc. 1971) 21-37; D.Z. Phillips, 
these ideas were right from the beginning countered by contemporaneous protagonists. ${ }^{4}$ For a fundamental attack on "the call to move beyond 'belief'" I may refer to Wiebe 1979, who forcefully argued that the study of religion(s) "is impossible without use of the concept (category) of belief." Wiebe's criticism is conclusive, particularly in his rebuttal of the argument that, since originally (i.e. in a Medieval Christian context) the verb 'believe' meant 'having faith' or 'pledging allegiance' and not 'holding an opinion', in consequence our modern equation of 'believing' with 'opining' should be illegitimate. ${ }^{5}$

Basically, we are confronted here with a clash between cognitive and non-cognitive concepts of religion. And to date it seems that the former have prevailed: the notions belief/believe are thriving in current cognitive study of religion. ${ }^{6}$ Or in the words of Wiebe p. 244: "The conclusion seems inescapable; to talk of religion is to talk of, besides commitments, ideas, interpretations and doctrines."

In the domain of Greek religion the 'new creed'7 of the 'non-believers' rather owes its inspiration to, and indeed has emerged as part and parcel with that other modish ideology, "the new orthodoxy of the

Religion without Explanation (Oxford 1976). For the preponderance of action (ritual) over belief (cognition) in anthropological study of religion see: J. Skorupski, Symbol and Theory (Cambridge 1976) $46 \mathrm{ff}$.

${ }_{4}$ To mention just a few: J. Hick, Faith and Knowledge (Ithaca NY 1966) 4: "Faith as trust (fiducia) presupposes faith (fides) as cognition of the object of trust;" A.B. Gibson, Theism and Empiricism (London 1970) 12: "Religion has an intellectual as well as a moral component. It is not a way of life imposed upon a state of affairs; it is a way of life with a conviction about a state of affairs built into it;" T. McPherson, Philosophy and Religious Belief (London 1974) 121: "To describe a belief as a commitment or an affirmation of trust, or something of the sort, does not in itself preclude the raising of questions about the grounds of that belief."

${ }^{5}$ Despite the rejoinder by W.C. Smith, Belief: A Reply to a Response, Numen 27 (1980) 247-255, who in his The Meaning and End of Religion (1962), had already argued against the use of the term 'religion' as well, inter alia with the very same etymological argument that the word religion goes back to (Latin) religio in Roman times (!). For a more general discussion see: $\mathrm{D}$. Wiebe, The Irony of Theology and the Nature of Religious Thought (Montreal-Kingston 1991). Cf. also M. Southwold, Religious Belief, Man 14 (1979) 628-644, in his altercation with Leach's very idiosyncratic reductionist views on religious belief. For a recent dispute between King 2003, who defends the use of the term 'belief, and the reaction by Giordano-Zecharya 2005, see below.

${ }^{6}$ J. Andresen (ed.), Religion in Mind: Cognitive Perspectives on Religious Belief, Ritual, and Experience (Cambridge 2001); J. Sørensen, Religion in Mind: A Review Article of the Cognitive Science of Religion, Numen 52 (2005) 465-494, espec. 470-475.

7 I am borrowing here an expression from the title of Yunis 1988, which I mention here for its free use of the term 'belief' throughout the book, however without venturing into the discussion about its legitimacy. 
foreignness of Greek society," ${ }^{\text {" that }}$ we have already encountered in the 'desperately alien' school earlier in the present book. For reasons of space and convenience I will restrict my own discussion to the ancient Greek context of the issue of 'belief/believe'.

Let us take our departure from an oft quoted candid passage by one of the earliest and most ardent devotees of the new creed, Simon Price 1984a, 10 f.:

Indeed the centrality of 'religious belief' in our culture has sometimes led to the feeling that belief is a distinct and natural capacity which is shared by all human beings. This, of course, is nonsense. 'Belief' as a religious term is profoundly Christian in its implications; it was forged out of the experience which the Apostles and Saint Paul had of the Risen Lord. The emphasis which 'belief' gives to spiritual commitment has no necessary place in the analysis of other cultures. That is, the question about the 'real beliefs' of the Greeks is again implicitly Christianizing.

It is also in the works of this author that the two basic tenets which, in the domain of classical studies, have paved the way toward this strange idea, become apparent. One is that Greek religion was ritualistic to such a degree that in fact ritual was the essence of their religion, while 'belief' (leave alone 'faith') was more or less negligible. The other is the near-paranoid fear of imposing Christianizing assumptions on foreign religions in general and on Greek religion in particular, as we already noticed in the earlier studies of, among others, Needham and Smith, just mentioned. Also in his more recent book on Greek religions Price 1999 never gets tired of drumming into his non-pagan readership the first commandment not to project their Christian ideas upon ancient customs. ${ }^{9}$ Here, too, he decides: "Practice, not belief is the key, and to start from questions of faith or personal piety is to impose alien values on ancient Greece." ${ }^{10}$

${ }^{8}$ E. Kearns, in her review of Gould's contribution to Easterling-Muir 1985, in: $C R$ 36 (1986) 259.

9 Thus beating it to death as noted by Kearns o.c. (preceding note) 258: "By the time we reach p. 36 we have been told three times that the Greeks had no sacred books and twice that they had no church... a repetition with a deadening effect."

${ }_{10}$ Note that this is less absolute a statement than the one quoted above. Yet also here Price tries at all cost to avoid the terms belief/believe, which may even result

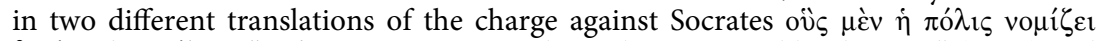
$\theta \varepsilon o v ̀ \varsigma$ ov voui $\zeta \omega v$ : "Refusing to recognize the gods recognized by the state" (p. 85) and "refusing to acknowledge the gods that the city acknowledges" (p. 126). Moreover, in other sections of this book Price does not shrink from using 'believe' and 'belief' in the sense used by all those Christianizing scholars that he censures. One instance out 
These two tenets were neither new nor totally unfounded or uncalled for. The first thing any beginning student of Greek religion gets drummed into his mind by his professor and his handbooks is that it fundamentally differed from Christianity in quite a number of features. Robert Garland, in the preface to his Religion and the Greeks (London 1994) under the title "How Greek Religion Didn't Work", presents a list of eleven well-known 'didnt's,' "a kind of negative catechism" as he calls it, including: the absence of dogma and of anything resembling a church with its hierarchy, as well as lack of a concept of conversion and a set of beliefs to which everyone had to subscribe. Or, in the lapidary formulation by Burkert 1985, 275: "A creed or confession of faith is as foreign to Greeks as the Spanish inquisition." All this may be deemed as long established and generally acknowledged.

As for the ritualistic trend, its roots lie in the late 19th century with W. Robertson Smith, who claimed $(1889,20)$ that "ritual and social usage were the sum total of ancient religions," a change of focus from myth to ritual which according to Nilsson GGR 1955 had attained its completion in the middle of twentieth century. ${ }^{11}$ The recent trend that we are discussing conveys the impression that since Nilsson's observation no major changes have occurred.

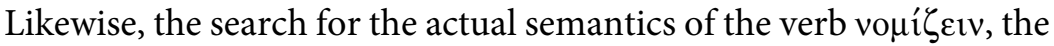
term which in a religious context is generally taken as closest to what we understand by 'believing', long antedates the recent craze of 'nonbelievers'. Fahr 1969 already gives the history of the debate among earlier philologists. Long before his book appeared, voices could be heard

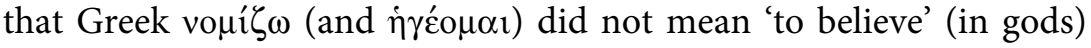
but should be interpreted from a ritualist, non-cognitive perspective as 'to worship gods with ritual acts.' The discussion centred on the famous charge against Socrates, where three independent sources, with slight variations, have handed down the formula: oỉs $\mu \grave{\varepsilon} v \dot{\eta} \pi$ ó $\lambda 1 \varsigma$

of many is his translation of Pl. Leg. 10.885b: "No one who believes that there are gods...."). Cf. Ch. VI n. 49.

11 "The reversal was complete: instead of myths, rites had come to the fore" ("Der Umschwung war vollendet: statt der Mythen waren die Riten in den Vordergrund getreten"), adding: "Since then there has not been any radical or essential change in method and direction of research." On the 'ritual turn' in the scholarly discussion of the late 19th and early 20th centuries, and the ever increasing interest in ritual proper since the 1960s see: J.N. Bremmer, 'Religion', 'Ritual', and the Opposition 'Sacred vs Profane', in: Graf 1998, 9-32, espec. 14-24. On 20th century theories concerning myth and ritual: Versnel 1993, 16-89. Cf. Kowalzig 2007, 13-23, for a useful critical discussion of the theories. 


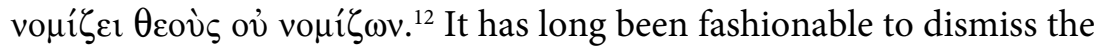
at first sight obvious interpretation "not believe in (the existence of) the gods." Instead, the expression should be understood as "not honour the gods by worshipping them according to (cultic) tradition." The charge, then, would be "one of nonconformity in religious practice, not of unorthodoxy in religious belief."13

Unsurprisingly, those recent scholars who believe that absence of matching terminology necessarily implies the absence of the concomitant concepts perform miracles to substantiate this one-sided

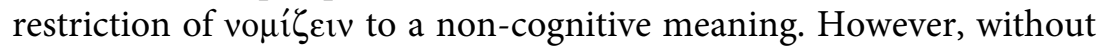
denying that for instance in Herodotus, and generally in texts before the mid 5th c. BC, voui $\zeta \varepsilon$ iv does prevail in the sense of 'to practice or observe as a custom or institution', a sense that naturally may be implied in the charge against Socrates, E. Derenne already in 1930 had been the first to show that the interpretation 'not believe in the existence of the gods (in the way it is traditionally done by the polis)' is a correct and sometimes irrefutable one in quite a few, particularly Platonic, passages. ${ }^{14}$ Following in his tracks, Fahr 1969 has shown that

${ }^{12}$ Favorinus ap. Diog. Laert. 2.40; Xen. Mem. 1.1.1; Pl. Apol. 24c. The authenticity is confirmed by the fact that Favorinus quoted the text from the official acts which were kept in the Metroon in Athens. M. Montuori, Socrate. Fisiologia di un mito (Firenze 1974) 362: "la sola testimonianza storica che abbiamo su Socrate." Cf. Brickhouse \& Smith 1989, 31 and my discussion in Versnel 1990, $124 \mathrm{f}$.

${ }^{13}$ I quote the formulation of J. Burnet, Euthyphro, Apology of Socrates, and Crito (Oxford 1924, many reprints) ad loc., who made himself the mouthpiece of the then popular view among philologists. K.J. Dover, Aristophanes' Clouds (London 1968)

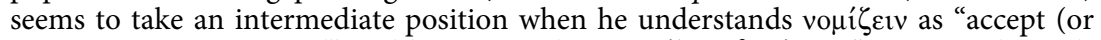
treat, practise) as normal" and hence translates voui $\zeta \varepsilon v v \theta \varepsilon o v ́ \varsigma$ as "to accept the gods in the normal way." For further discussion see below.

${ }^{14}$ Derenne 1930, 217-223, whose perfectly convincing argument rests on the following passages among others: Pl. Apol. 26C; 27C; 35D; Leg. 10, 885BC; Xen. Mem. $1.1 .5 ; 1.1 .20$. In these texts Socrates explicitly defends himself against the idea that he does not believe in the existence of gods. Rudhardt 1960, 91 in this connection

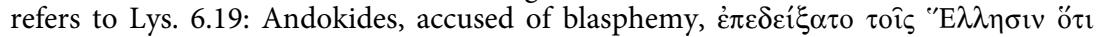

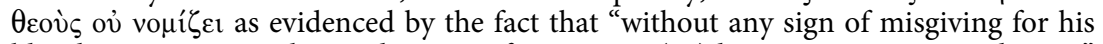
blasphemous actions, but with an air of assurance, (...) he went voyaging on the sea." Even less equivocal is Lys. 6.51, on the mystery gods of Eleusis derided by Andok-

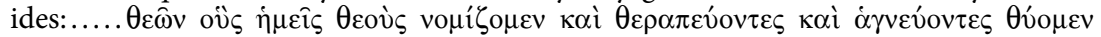

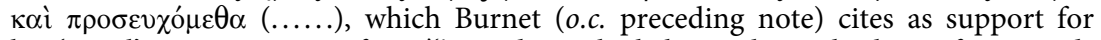
his 'ritual' interpretation of voui $\zeta \omega$ and in which he explains the latter four words

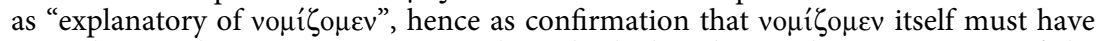
a similar ritual sense. Quite conversely, I think that the emphatic repetition of the word $\theta \varepsilon o v$ s-so surprisingly emphatic that Reiske wished to delete it-exactly points to the contrary. The implied meaning is that Andokides and his companions do not acknowledge the Eleusinian deities as gods-hence scoff at them-while the accus- 
in Xenophon and Plato, albeit with different overtones, both meanings can be established but that in Plato the 'cognitive' notion prevailed. After his arguments it can no longer be questioned that the latter part of the fifth century witnessed a gradual shifting from "die Götter nicht nach Brauch ehren" towards "die Existenz der Götter nicht für wirklich halten." The latter sense is explicitly expressed in Aristophanes (especially the Nubes) and Euripides and is almost certainly intended in the charge against Socrates (and probably implied in Diopeithes' decree, on which the charge was based). ${ }^{15}$ The double meaning of the term is perhaps best rendered by English 'acknowledge.' We will return to this part of the discussion later.

As said above, Price is not alone in his sceptical stance. Numerous authors have expressed similar ideas on the imbalance between ritual and 'belief', though rarely adopting the extreme stringency of Price's earliest statements quoted above. Their utterances are mostly of the nature of occasional comments scattered in works of a wider tenor. Apart from one paper, to be dealt with below, I do not know a monographic publication on the issue. This implies that the following testimonies are random, and, if indeed exemplary, certainly not exhaustive: ${ }^{16}$

To the ordinary Greek, festive and ceremonial occasions were the primary constituent of religion; theology came a very bad second. (K.J. Dover, Aristophanic Comedy, London 1972, 33)

Greek piety, Greek Religion (...) appear to be a matter of rituals, festivals, processions, games, oracles, sacrifices-actions, in sum-and of

ers do believe these gods to be gods-hence pay cultic respect to them with sacrifice and prayer. So my translation would be: "the gods, whom we believe to be gods (or: acknowledge as gods), and to whom-in reverence and pure condition-we bring sacrifice and prayer."

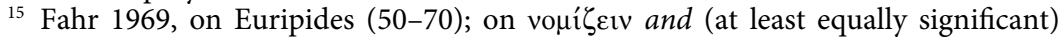
$\dot{\eta} \gamma \varepsilon \hat{\imath} \sigma \theta \alpha \mathrm{l}$ in Aristophanes (71-84) (M. Montuori, Socrate tra Nuvole prime e Nuvole seconde, AAN 77 [1966], persuasively stresses the marked resemblance between the Aristophanic parody of $423 \mathrm{BC}$ and the real accusations of $399 \mathrm{BC}$.); on Xenophon (113-122); on Pl. Apol. (131-152). Brickhouse \& Smith 1989, 31 give a list of the most decisive arguments. One is that Xenophon Mem. 1.1.2-5, too, understood the charges against Socrates to involve atheism. For doubts on the historicity of the Diopeithes decree see: K.J. Dover, The Freedom of the Intellectual in Greek Society, Talanta 7 (1976) 24-54.

${ }^{16}$ King 2003, 276 n.4, mentions more relevant testimonies. For critical notes on using the term 'belief' for Roman religion see: C.R. Phillips, The Sociology of Religious Knowledge in the Roman Empire to A.D. 284, ANRW 2.16.3, 2677-2773, espec. 2697-2711. 
stories, myths, about concrete instances in the working of the deities, not of abstract dogmas." (M.I. Finley [ed.], The Legacy of Greece: A New Appraisal, Oxford 1981, 4) ${ }^{17}$

In the older world of the polis human solidarity (i.e. as embodied in common ritual) was more important than the exaltation of faith. (Burkert 1985, 275)

One thing, though, is pretty clear. Classical Greek religion was at bottom a question of doing not of believing, of behaviour rather than faith. (P. Cartledge in: Easterling \& Muir 1985, 98)

The central Greek term theous nomizein means not 'believe in the gods', but 'acknowledge them', that is pray to them, sacrifice to them, build them temples, make them the object of cult and ritual. (J. Gould in: Easterling \& Muir 1985, 7)

It was above all the observance of rituals rather than fidelity to a dogma or belief that ensured the permanence of tradition and communal cohesiveness. (Bruit Zaidman \& Schmitt Pantel 1992, 27)

What mattered was the performance of cult acts, not the state of mind of the actor. In as far as individuals were recognized as especially 'religious' it was for what they did, not for what they thought. (R. Osborne in: Alcock \& Osborne 1994, 144)

It is only in a religious context where beliefs determine choices, that believing as such becomes a central element in the system. Religious 'experiences', 'feelings' or 'beliefs' must have had quite different significances and resonances in early republican Rome. (M. Beard, J. North \& S. Price, Religions of Rome, Vol. I History, Cambridge 1998, 43).

Such for the greater part more moderate utterances will not raise serious objections. ${ }^{18}$ As said before, the fact that ancient religious expression is of a ritualist rather than a confessional proclamatory nature is a truism. However, this truism may evaporate into hot air when the notion of proportionality must give way to suggestions of exclusivism

${ }^{17}$ At p.65, however, he reports that "Socrates was accused of a specific form of impiety; namely that he disbelieved in the city's gods" (!). One of the many instances of inconsistency among the new sceptics. Cf. above n. 10 and Ch. VI n. 49.

${ }_{18}$ Certainly not if for instance Bruit-Schmitt (p. 27) after stating, as quoted, that Greek religion is basically ritualistic, continues: "however, this Greek ritualism did not exclude either religious 'thought' or religious 'beliefs'." It should also be noted, as Harrison 2000, $18 \mathrm{f}$., reminds us and illustrates with quotations, that the authors here cited in their more detailed discussions often present a different and less absolute variant of their generalizing formulations. Yet, also in his view: "there are a number of significant overstatements in this modern creed that need to be challenged." And so he does. 
and incompatibility. After Price's rigorous statements quoted above, such ideas are most provocatively represented in recent titles such as: "As Socrates shows, the Athenians did not believe in Gods" or "Quand faire, c'est croire" (When doing/acting is believing). ${ }^{19}$

The first thing that strikes the reader is that with few exceptions these utterances, both the moderate and the extreme ones, usually are devoid of anything resembling evidential substantiation. They are axiomatic assumptions rather than inferences drawn from ancient evidence. This is true for both main tenets that were mentioned above:

1) 'belief' as a religious term is profoundly Christian in its implications and hence should not be applied to the study of Greek religion,

2) a predominantly ritualist attitude on the one hand, and lack of dogma, authoritative sacred books, professional clergy on the other preclude theological reflection and imply absence of the notion belief.

It is exactly these general suppositions that a recent wave of critique sets out to tackle. ${ }^{20}$ After having briefly expressed some doubts in Versnel 1993, I will now expound my own considerations as they have developed inter alia with the aid of relevant observations by four scholars who have recently commented on the issue: Naerebout, Harrison, Feeney, and King. ${ }^{21}$ I will summarize their views, explicitly lauding individual authors only when they advance an argument that does not occur in any of the others or offer a particularly apposite wording.

${ }^{19}$ M. Giordano-Zecharya, As Socrates shows, the Athenians did not believe in Gods, Numen 52 (2005) 325-355; J. Scheid, Quand faire, c'est croire: les rites sacrificielles des Romains (Paris 2006) and cf. M. Linder \& J. Scheid, Quand croire c'est faire. Le problème de la croyance dans la Rome ancienne, Archive de Sciences Sociales des Religions 81 (1993) 47-62.

${ }_{20}$ Since without exception the critical comments, like their sceptical targets, occur as more or less independent fragments in works on more general topics, I do not claim to have seen all.

${ }^{21}$ Versnel 1993, 124-131; Naerebout 1997, 331 f.; Feeney 1998, 12-21; Harrison 2000, 18-23; King 2003, 275-312. Feeney and King focus their attention on Roman religion and share a plea for a context-specific approach, acknowledging a variety of 'beliefs', the first with respect to various departments of life, literature and culture, the second on various sections of religion. Their common thesis is that different modes of belief are mobile, competitive but not mutually exclusive, and potentially marked by different discourses. In Feeney's words: "The co-existence of the genres of belief does not prove their impotence, but is rather the very condition that makes meaning possible," while King argues for an "essentially polythetic nature of Roman religious organization, in which incompatible beliefs could exist simultaneously in the community without conflict." All this, in short, is what Veyne referred to as "balkanisation of the brain" (see for this and related terminology above Ch. I n. 226) and what, in different terms, I have tried to elucidate throughout the present book. 
Starting with the general arguments of the sceptics, King 2003, 277 remarks that Needham's two main arguments as cited above contradict each other. If belief is specifically Western or Christian it must have a specific meaning or an identifiable range of meanings. But if a word has no specific definition (as Needham claims for 'belief') how could one know whether or not it could be rendered into e.g. the Nuer language (as Needham also claims)? King certainly has a point here, ${ }^{22}$ but the kernel of the problem emerges when most sceptics do claim to know the precise meaning of belief/believe, namely by identifying it with-and restricting it to-its uses in Christian theological discourse in its overtly confessional, dogmatic and historically fixed sense. It is here that things tend to go off the rails. For why must 'I believe in God' inevitably imply an extended set of doctrinaire connotations, whereas "I do not believe in God" in everyday vernacular just means "I do not believe in the existence of (a) god?"

Rather we should attack the whole problem in more generic terms. The most general and comprehensive meaning of 'to believe', to be found in modern dictionaries (often as the first item and quickly gaining field in our rapidly secularizing times) is: "to hold a thing for true without being able to prove it." ${ }^{23}$ This is the course of action chosen by King 2003, 278, who proposes the following definition: "Belief is a conviction that an individual (or group of individuals) hold independently of the need for empirical support." And he adds:

Far from being 'implicitly Christianizing' belief is not even intrinsically connected with religion or religious concepts (.....) The central element is not the conscious assertion of belief, but rather the existence of a conviction in the absence of a need for verification. ${ }^{24}$

${ }^{22}$ Giordano-Zecharya 2005, 344 n. 54, reproaches him with simplifying the complexity of Needham's arguments, and also that he "appears to miss the issue of the semantic status of belief as I have outlined it." As to the latter (on which see below pp. 548-554) it would be more to the point to say that King and Giordano-Zecharya (whose arguments King could not know at the moment of writing) appear to differ in their approach to and assessment of the notion 'belief'.

${ }^{23}$ I realize that in this respect there is a disparity between 'believe' and 'belief', the noun being more commonly associated with Christian notions. However, all 'sceptics,' even when they start by focussing on the noun, continue freely projecting their critique onto the modern use of the verb 'believe' (as Giordano-Zecharya 2005, 330, n. 18 explicitly does, and cf. the titles cited above n. 3), whereas the lexicographic discussion is entirely focussed on the verb vouí $\zeta_{\varepsilon 1 v}$

${ }^{24}$ I add here a more extended definition by the literary critic Kirwan 1990, 144, whose implications seem to be particularly relevant to our present discussion: "We can define 'belief' as the acceptance of the existence of a certain state-of-affairs, the 
And so it is. The argument of Smith o.c. (above nn. 3 and 5) and others that 'believing' originally meant 'having faith' or even 'to pledge allegiance to' (and that our word 'belief' still betrays traces of those connotations) is in this respect irrelevant. If one still fears a jamming of interfering connotations one can use 'to acknowledge (as true)' but it denotes exactly the same. Scholarly discourse is always etic and should therefore be conducted in etic terms. This means that the person who engages in this type of research must clarify that (s)he will use the term 'believe' in its broad 'low intensity' meaning and not in its Christian 'high intensity' application with all its well-known implications. ${ }^{25}$

This would be also my response to the recent argument-very much in line of Needham's work-of Giordano-Zecharya (henceforth Giordano) 2005, 343-347, who censures King for defining 'believe' as just quoted, as well as others who keep using the word 'believe' in descriptions of non-Christian religions in the sense of "holding as true," since this, too, she argues, runs the risk of confusing Christian and non-Christian contexts. Why, she concludes, run the risk of wrapping our understanding, when other terms such as conviction, opinion or understanding are available? Giordano's verdict is grounded in her own specified definitions regarding the 'semantic field' of 'to believe', and in particular on the inferences she draws from their supposed interrelations:

a) Asserting the truth or the existence of something or somebody (in its use of "to believe that", "to believe something").

b) Holding as a subjective opinion, to suppose, again in the verbal construction "to believe that".

c) Having confidence in, trusting, in the expression "to believe in" and "to believe somebody".

She thinks that

in non-religious settings, the context selects one of these settings: in religious settings such a selection is no longer possible. In the expression

putting of one's trust in the truth of a statement, or the efficacy of a principle. But belief may be more or less explicit, and our use of the word 'believe' extends from the description of knowledge, direct acquaintance with a state-of-affairs, to opinion, or belief based on grounds short of proof, that is provisional conviction."

${ }^{25}$ I take the terminology from J. Van Baal, Offering, Sacrifice and Gift, Numen 23 (1976) 161-178, espec. 169-173, who makes a distinction between these two kinds of sacrifices. 
"to believe in god" unlike in the expression "to believe in a friend," the selection is not only sense c) (having trust in God), but also sense a) (asserting the existence of God).

And she deems it specific for Christian and generally modern use of the word that in fact it subsumes three senses, inextricably (my italics).

It seemed necessary to me to insert a rather extensive discussion of her views (both here, on the meaning of belief/believe, and below, on

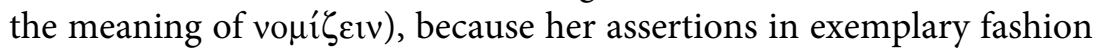
reveal the pitfalls hidden in the whole issue. The definitions and implications just quoted evoke inter alia the following considerations:

1) How do we draw the line between 'religious' and 'non-religious' uses of the word 'believe'? Is that between 'God' and 'friend', or also between God and god(s)? Should not first the term 'religious' in the phrase 'religious setting' be defined? Should we call a setting 'religious' when any notion god, or solely when the notion God with its inherent associations is involved? Is perhaps the criterion 'religious' not primarily determined by the setting of the issue under discussion but rather by the mental baggage of the reseacher? Which brings us to a further observation:

2) I would call into question the general validity of the qualification 'inextricably' for the concatenation of two or three senses of 'belief' in a so-called 'religious' setting. And this not only when god(s), but even when God is the object of the verb 'believe'. If ever sense a) and c) are inextricably interwoven this will be only in the mind of those language users that consciously or unconsciously experience sense c) as an inevitable and inextricable connotation of the expression 'believe in God'. However, in the current intellectual debate on the 'existence' of God, one may notice even faithful Christians participating without implicating traditional Christian qualities of God. Accepting the conditions for partaking in such a debate and its discourse they have to change their confession from "I believe in God" (senses $a+c$ ) into "I believe in a god" or rather "I believe in the existence of a god" (sense a). By intentionally and explicitly selecting sense a and (momentarily) disregarding sense c, they even seem to have access to two gods, the one of Sunday, written with a capital and provided with all the qualities, attributions and paraphernalia as conferred by Holy Scriptures, church and tradition; the other, 'ein Gott ohne Eigenschaften' whose main raison 
d'être is to function as a kind of Xenophanean creative intellect and as such being held responsible for the Big Bang. If all this is conspicuously possible in the case of faithful Christians and their God, how much more self-evident is then the choice of sense a) (without any further connotations) in the case of non-Christians discussing Greek gods? For them the phrase "the Greeks believed in gods" falls into the same category as "(the/some) Greeks believed in phantoms, monsters, miracles and afterlife," which implies the selection of sense a: 'asserting the existence of. And, in the words of King, there is nothing intrinsically religious in that. A general denial of the mental aptitude to such selective agility is in our present intellectual climate nothing more than a (Christian) parti pris grounded in long superseded preconceptions. There is, however, another, even more relevant, third consideration:

3) The language user (Christian or not) is not even dependent on an explicit and conscious decision to avoid inextricable concatenations of a and c. It is the mere context in which the notion 'god' is brought up that automatically evokes in the mind of speaker or listener the appropriate type of 'belief': a) or c) or both. For "it is the context which makes it possible for the language user to filter out from the various possible meanings of polyvalent words or expressions all except the 'desired' ones." 6

If Greeks can unreflectedly switch from one common Greek Zeus to a very particular and different local one; if Xenophanes in an ongoing text can shift from One God to many gods-and back-; if in a coherent piece of literature a god is omnipotent at one moment but at the next cannot do anything he wants-and all this depending on context and discourse as we have seen in the present book-then it bears witness to an objectionable ethnocentric bias if we clear ourselves of similar frailties/qualities of the mind, capacities which, moreover, are widely acknowledged and researched in various scholarly disciplines that we have adduced in the present book. Altogether we must conclude that the hard and fast definitory rules as devised by Giordano simply do not work in the practice of the language user the way she wants them to. The title of her paper remains challenging but is so far

\footnotetext{
${ }^{26}$ As I wrote in Versnel 1990, 17, to which I refer for an extensive discussion and literature on the fundamental importance of context and related issues.
} 
unproven. Below we will check whether her semantic exercises con-

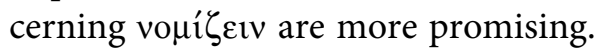

In fact we have landed here in the same discussion as the one that occasionally erupts on the legitimacy or usefulness of the terms 'religion' (already as early as W.C. Smith 1962, cf. above n. 5) or 'magic' in the study of non-Western cultures. Both stand under suspicion of harbouring a hoard of modern connotations, inspired by Christian tradition. For religion that would be the notion of belief and the idea of a strict separation between the secular and the religious spheres; for magic it would include its inherent negative flavour. This discussion is just as senseless-if alone because it inevitably entails an unviable result—as the one about 'belief/believe' and just as unnecessary. "Magic does not exist, nor does religion. What do exist are our definitions of these concepts," thus the opening sentence of an article on magic with a plea for an etic course of action. For religion there is a recent article in which the author exhibits and convincingly rebuts current theories that propose "to abandon the academic concept of religion and replace it with an emic concept." ${ }^{27}$ It is this stance that I adopt in the present discussion: in scholarly discourse we have no other choice than using etic terminology, which of course we must define before launching it.

Returning to the notions belief/believe there are yet a few questions that are in need of further consideration. If it is allowed now to say that (the) Greeks believed in (the existence of) gods, what then about the alleged fundamental differences between Christian and ancient Greek religious 'beliefs'? Are they as stringent and pervasive as the sceptics claim? If, for the sake of argument, we agree for a moment that Christians may be assumed to believe in a particular Christian way, how intensive and inclusive is that belief in the practice of every day, including every Sunday? Roman Catholic and Eastern Orthodox church services simply live on ritual and this includes the spoken and sung parts as fixed in formulaic prayer and litany. The Protestant service, deemed to be poor in ritual, has been claimed to be in fact a ritual

${ }^{27}$ H.S. Versnel, Some Reflections on the Relationship Magic-Religion, Numen 38 (1991) 177-197; A. Lindberg, The Concept of Religion in Current Studies of Scandinavian Pre-Christian Religion, Temenos 45 (2009) 86-119. In her abstract she states that according to her opponents "the concept of religion obscures the specific character of religions of (...) societies of the Pre-Christian Age." The italics are mine and I am not sure whether this obvious token of the unmanageability of a ban on the term 'religion' is intentional. Both papers provide a discussion of earlier literature and I refer to them for further information. 
in itself. ${ }^{28}$ Is Christian belief, for the most part being inherited and hence no matter of choice, in daily practice really more consistently and consciously devotional than other beliefs? Is not more often than not reciting the Apostles' Creed rather an act of ritual than of conscious belief? ${ }^{29}$

Moreover, what is the Christian creed? Is it less diverse than nondoctrinaire religions like the ancient Greek one? In theory, as confessed in High Episcopal or Calvinist circles, there is one common central belief in one God, one Mother of God, one Son of God (who may be or not be God himself) and one Holy Spirit. But in our first chapter we met a majority of believers who did not at all comply with this central doctrine and manifested a considerable flexibility concerning the one or different identities of the numerous Mothers (and their Sons). Hence, "the monothetic character of religions like Christianity and Islam will always be greater in theory than in practice" (King 2003, 283).

On the other hand, the fact that Greek religion was basically a matter of ritual action in no way implies the consequence that Greeks did not believe in (the existence) of their gods. This would indeed imply a contradiction: how does one communicate with divine beings through prayer, gift-giving, and attributing them a full scale of anthropomorphic (and allomorphic) features that we have been discussing throughout the present book, without believing (that is taking as true) that these beings exist (in whatever sense of the word 'exist')? The prerequisite of all these actions, especially prayer ${ }^{30}$ is the belief that gods have power and are willing to interfere in human life. How would they do that in the perception of the worshippers without existing? Stating that Greek religion is ritualist and at the same time that "the Athenians did not believe in their gods" is either nonsense or a kind of sophistry run wild, which should be banished from scholarly discourse. Side by side with, and indeed quite independent of, their ritual concerns,

\footnotetext{
${ }_{28}$ Thus Naerebout referring to W. Jetter, Symbol und Ritual. Anthropologische Elemente im Gottesdienst (Göttingen 1978) 89.

${ }^{29}$ R. Mellor in his review of Price 1984, AJPh 107 (1986) 298, rightly reproaches Price with reducing all Christian religiosity to "low church Victorian Protestantism."

${ }^{30}$ Understandably, the existence of prayer is not lacking in any of the defences of 'belief', but I refer to King $281 \mathrm{f}$. for a particularly compelling argumentation leading to the conclusion: "One must first internalize the belief that a god exists before one can believe that the god has any specific power."
} 
Greeks put their belief in the existence and interventions of (the) gods in the service of their need for 'making sense' of unaccountable (most frequently catastrophic) events, as we have seen in Chapter II. Comparably, central elements of Greek religion, such as divine epiphanies and divination, are not conceivable without the notion of belief in (the existence of) gods.

As for the typical elements of dogma, clergy, confession and conversion, they denote ways in which one type of religion has moulded its identity in our Western-Christian culture. But this does not imply that a religion where these expressions are lacking or less prominent is also devoid of something that in more general terms we also call 'belief'. It is exactly here that the arguments of the new 'sceptics' are infested with non sequiturs. In the words of Harrison 2000, 20: "To seek to describe Greek religion by means of a stark opposition of ritual and dogma is little more than to offer a choice of two caricatures."

With all this we are not imposing our notions on our Greeks. True enough, the question whether gods exist would puzzle them, since gods' existence was obvious, having come as part and parcel of their social knowledge, hence was no matter of discussion in everyday life. However, as we have seen in Ch. III, traces of a discourse on 'the truth' of the traditional gods emerged early in philosophy. In the 5th century Diagoras gained his epithet atheos not only for despising and mocking but also for straightforwardly denying the (existence of) gods. How can one person deny (the existence of) gods unless (all) others do believe that they exist? And as soon as two slaves, Nicias and Demosthenes, in Ar. Equ. 30-34 have a discussion like the one following, we do have a relevant discourse on the belief in gods, just as there are more isolated reflections of a potentially 'atheist' nature at other places in Aristophanes, in the charge against Socrates, and elsewhere.

N. It is best for us now to fall (

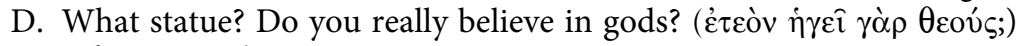

N. Of course I do.

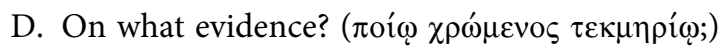

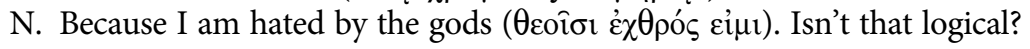

So, in the end the question that prompts itself is: who is the one that is imposing Christian notions on the issue? In the mind of the present writer, albeit of Protestant Christian origin, the expression 'to believe in god(s)' does not compulsively evoke any of the Christian connotations that Price and others associate with it. Resistance to using the word 
'belief/believe' can only be a pressing option for those who are still, even if aversely, under the sway of their Christian heritage and assume that every other contemporary scholar submits to the same yoke. In other words: the statement that the ('religious') notion of 'belief is an exclusive privilege of the Christian creed and consequently can only be used with the full array of its Christian connotations is nothing less than an instance of modern Christian bias. ${ }^{31}$ In this context Feeney aptly points out the distinction between the 'modern Christianity' that is at home in an age in which unbelief is envisaged as the normal position, and the Christianity of earlier ages in which complete unbelief was scarcely imaginable. It is only this earlier stage of Christianity that might rightfully evoke the dangers listed by the sceptics. For the rest it has become clear by now that "there is common ground between Christianity and Greek paganism at the general level of belief" (King 283).

May we then, reviewing this range of arguments, safely conclude that the question "did the Greeks believe in gods" is intrinsically absurd, but if for the sake of argument taken seriously (and taken in its 'low intensity' sense), should be answered in the positive? Not yet, alas, for as appears from the title of her paper "As Socrates shows, the Athenians did not believe in Gods," Numen 52 (2005) 325-355, M. Giordano-Zecharya (henceforth Giordano), has recently argued for exactly the opposite. The paper "reopens the discussion of key terms of the Socratic indictment, such as 'worship' and 'belief', from the point of view of Athenian religiosity," hence focuses on the famous charge

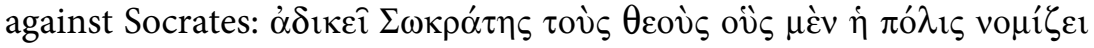

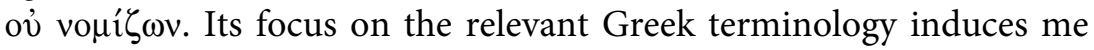

31 'To avoid the term 'belief' on the grounds of its association with Christianity is surely to privilege Christianity" writes Harrison 2000, 20, very to the point. I have not seen one review that does not censure Price's obsessive fear for Christianizing projections. N. Robertson in his review of Price 1999 (Phoenix 55 [2001) 449) suggests that Price's "interest in comparing Greek religion with Christianity (...) may derive from his teaching at Lady Margaret Hall in Oxford." Albeit calling it "one of the book's strengths" he lists some serious objections to Price's argument. More to the point R. Mellor, AJPh 107 (1986) 296 ff. and R.M. Grant, CPh 82 (1987) 174-178, in their reviews of Price 1984, quote Price's own allusion to his "growing up in an Anglican cathedral house" and his dedication to the memory of his father, a bishop of the Church of England, as the more direct roots of the author's "peculiar sensitivity to 'Christianizing assumptions' which he seems to find under every bed." Nonetheless (or rather consequently?) they find an astonishing number of inconsistencies in his book, where P. himself falls prey to using Christian notions in his own interpretations of his pagan material. 
to devote another brief discussion to her ideas. Giordano translates the famous charge as "Socrates offends the gods that the polis worships by not worshipping them." "32 She lists a considerable number of scholars including Robert Parker ("no argument, however, can remove the charge of atheism from the formal indictment against Socrates") and even Simon Price ("scandalous beliefs concerning the gods") who rather than the notion 'worship' opt for 'believe in' as a translation for voui $\zeta \varepsilon v$ in this text. Giordano contests this interpretation, in which she lets herself be guided by two convictions: first, that she can prove

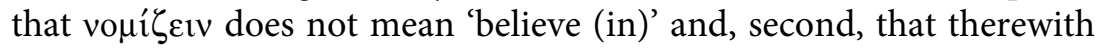
she will have proved that "the Greeks did not believe in their gods." 33 The latter idea rests on an error. Even if it could be demonstrated that Greek does not have a word that would match our term 'belief/believe', this would never prove that the Greeks might not have a matching concept. ${ }^{34}$

For a discussion of her first and main thesis concerning the word

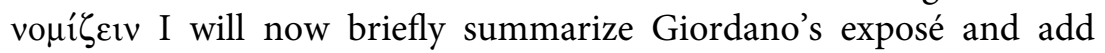
my comments wherever necessary. She first relates the history of the research with its ritual interpretation ("honouring the gods") in the early twentieth century, next, with Derenne 1930, the reversal to the view that Socrates was accused of atheism ("not believing in the gods"), ending with Fahr 1969, who interprets the expression as a charge against the denial of the existence of the gods, but argues that the word is

${ }^{32}$ There seems to be quite some confusion here. In her transcription of this text (the Greek texts are, if at all, given in transcription only) Giordano omits hous (oüs) which is a trifle-, and introduces a new, very idiosyncratic translation-which is no trifle because it is certainly mistaken. Apparently she takes the acc. theous as depending on adikei. But adikei is formulaic in official juridical language as the opening of an indictment in the sense of "he/she does wrong in the eye of the law, the particular

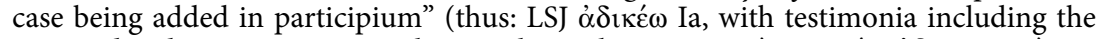

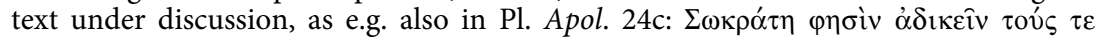
véovৎ $\delta 1 \alpha \varphi \theta \varepsilon i$ pov $\tau \alpha$ ). So the only correct interpretation is: "S. does wrong" (= is being accused), whereas theous depends on ou nomizon and stands in syntactical equivalence with kainous theous eisegoumenos.

${ }^{33}$ Throughout her article Giordano uses the term 'Greeks' (like all those whose theories she follows) instead of 'Athenians' in her title. I shall follow her in this.

${ }^{34}$ Cf. King 2003, 277: "Translating concepts is far more complex than equating individual words in a direct word-to-word translation. To show that a word from culture A represents a concept that does not exist in culture B, one would have to show that the concept could not be paraphrased into the language of culture B using concepts that already existed in culture B." He refers to D. Davidson, On the Very Idea of a Conceptual Scheme, in: Idem, Inquiries into Truth and Interpretation (Oxford 1984) 183-198. 
ambiguous and may shelter both meanings. Like other scholars, but more extensively, she analyses the difference between English 'believe' and Greek voui $\zeta \varepsilon v v$, concluding that despite some overlap between the two "the notion to believe in gods" is inapplicable to the Greek verb since the verb refers always (my italics) to customary practices and means 'venerating'/'worshipping', particularly in the form of prayer and sacrifice. So far her discussion does not go beyond a demonstran$d u m$, since at this point her reference to the thorough investigation by Fahr 1969 fails to mention the ambiguity and shift in the meaning of vopi $\zeta \varepsilon v v$ as discussed by that same author.

Scholars have thought to find expressions of unbelief in some passages of Aristophanean comedy, which, however, lack the word voui $\zeta \varepsilon v$. Here Giordano argues that expressions such as "Zeus does

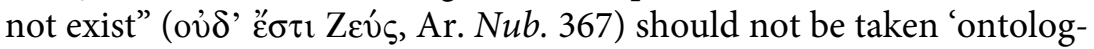
ically' but 'axiologically', meaning that "Zeus is 'usurped' by another god, hence is 'deauthorized' and lost his position." Even if we would grant her this at this place, this does not justify her translation at Nub.

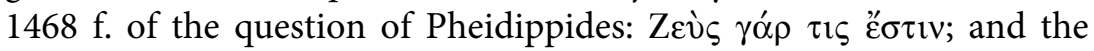
answer of Strepsiades: ह̌ $\sigma \tau v$ as: "As if Zeus was in power.... Of course he is." Here her wish to explain all these testimonies as tokens of 'deauthorization' (also by interrupting cult and sacrifice as in Nub. $423 \mathrm{f}$.) and not about renouncing the existence of gods, induces a misleading translation, which, moreover, the reader cannot check since the Greek original is not given, not even in transcription. ${ }^{35}$

Concerning the wording of the charge against Socrates Giordano contends that Xenophon conducts his defence of Socrates in line with a ritualistic interpretation of the word vouí $\varepsilon \varepsilon v$. In Mem. 1.1.2. and Apol. 11 the question is posed on what evidence Meletos grounded

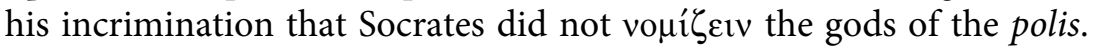
Giordano translates the Greek verb as 'venerate' and 'worship' respectively, on the grounds that in both texts Xenophon tries to refute the charge by referring to Socrates' sacrificial and divinatory activities. As I argued above (n.14) against Burnet, this can never be a conclusive

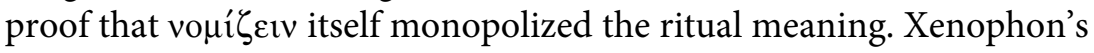

${ }^{35}$ It is highly inconvenient if not detrimental that the author throughout her paper refrains from providing the readers with the Greek texts and thus deprives them of a-not seldom necessary-occasion to check her translations on the spot. On the passage under discussion see: P. Brulé, Contribution des Nuées au problème de l'incroyance au $\mathrm{V}^{\mathrm{e}}$ siècle, in: Brulé 2009, 49-67, espec. $61 \mathrm{f}$. 
argument at least can be-and in my view, is best-understood as: if a person's words regarding things divine may have given cause to misunderstanding, then what he really 'believes' can only be retrieved through his visible or tangible behaviour. If a person prays or brings

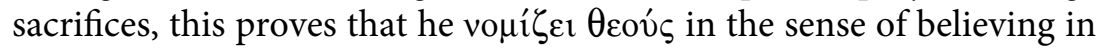
the existence of gods. Just as in the third testimony in Xen. Mem. 1.3.1, where this substantiation of Socrates' correct religious stance is also sought in his behaviour concerning the Pythia's responses, sacrifices, cult of ancestors etc. This passage itself does not contain the word vopi $\zeta_{\varepsilon i v}$, but what Giordano does not tell the reader is that the term does occur in the immediately ensuing phrase: "that hence Socrates

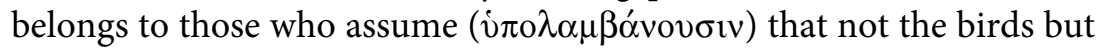
the gods make these things known. And that was Socrates' belief too (غ่vó $\mu \iota \zeta \varepsilon v) . "$ This, of course, does not directly refer to belief in the gods, but at least shifts the issue at hand from ritual to (cognitive) conviction. In sum, not one of Xenophon's texts proves that "Aristophanes and Xenophon concur in drawing a picture that Socrates was accused of irregularity in worship."

In the ensuing section under the title "Plato's semantic turn," Giordano first avers without discussion that in various places Plato uses

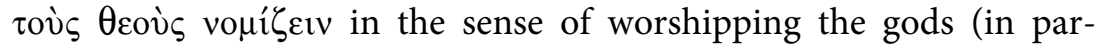
ticular Apol. 24c). But when Socrates starts defending himself, Plato

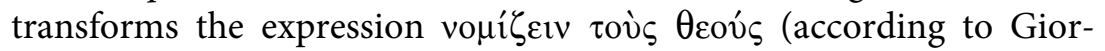

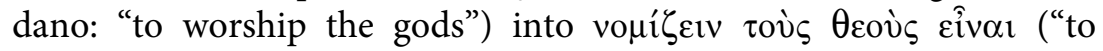

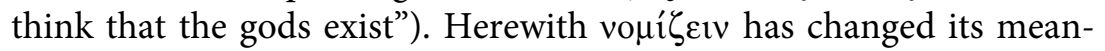
ing into "thinking that" and "this meaning reverberates throughout the whole Platonic interpretation, as if eivol were implied in all the

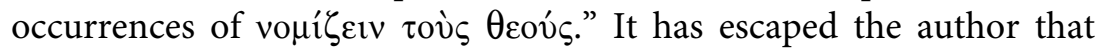
this presentation of the facts is inconsistent with her earlier statement that the Greek verb always refers to customary practices and means 'venerating'/'worshipping', particularly in the form of prayer and sacrifice, as well as with her assertion of a few lines before concerning

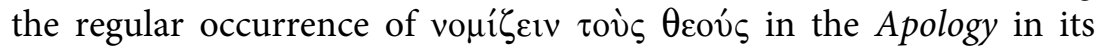
traditional meaning of "worshipping the gods," and particularly so in the accusation of Meletos.

The latter idea makes the only real difference with the extensive and thorough discussion by Fahr 1969, 131-157, whom she follows in both his survey of the meaning of the various expressions and in his (and others') explanation of this typically Platonic turn. Different from Giordano, however, Fahr concludes that all occurrences of 


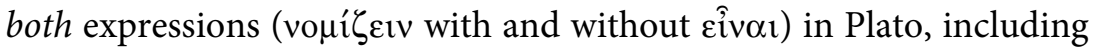
the wording of the charge against Socrates itself, should be taken in its cognitive sense of "(not) believing in the existence of the gods." $\mathrm{He}$ emphasizes that this interpretation must be consistently maintained even if he finally prefers to translate the verb as "für wirklich halten" ("acknowledge as real"), just as others prefer the expression "to acknowledge", which, I repeat, is nothing else than 'to believe in' in its 'low intensity' sense.

At this point Giordano's arguments have come to an end. Has she proved the thesis so proudly announced in her defiant title? Far from it. I have shown that neither her arguments concerning the modern

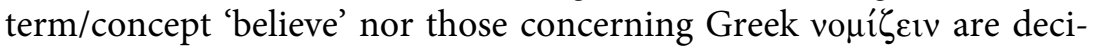
sive, to put it (very) mildly. As to her central issue, the wording of the charge against Socrates, the maximum we may conclude is that it remains open to variant interpretations. Here we can only argue in terms of plausibility. Ironically enough, what Socrates does show

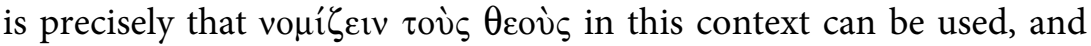
in Plato henceforth is consistently being used, in the sense of "believe in the existence of gods." All this we have now seen. The real problem, however, lies in what we have not seen, namely evidence and

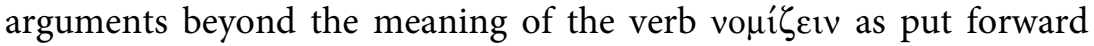
by Fahr and both earlier and more recent scholars (but completely ignored by Giordano) for the idea that the Greeks did believe in their gods. In this respect there are three major lapses in her treatment:

1) Questions about the existence of gods did emerge in the later part of the 5th century. Sometimes they took the form of cautious doubt as in the famous phrasing of Protagoras (D.-K. 80 B4): "About the gods I cannot know, neither that they are nor that they are not." Whether this should be understood as a token of an agnostic or of an atheistic stance, options that were already under discussion in antiquity, is immaterial for our discussion here. Sometimes we find expressions of a less equivocal atheistic stance as in the words of a character in Kritias' Sisyphos (D.-K. 88 B 25) and as ascribed to Diagoras.

2) The expression $\theta \varepsilon o v \dot{s}$ i $\gamma \varepsilon \hat{\imath} \sigma \theta \alpha$ in the unambiguous sense of "believe in gods" is attested already in the last quarter of the 5th c. BC. We have quoted one clear passage from Ar. Equ. 30-34 above and an even more explicit testimony in Aristophanes' Birds p. \#. Fahr 77-80, mentions Eur. Hec. 799-801 (ca. 424 BC, together with Ar. Equ. its first attestation); El. 583 f., Bac. 1325 f.; Pl. Ap. 27 d-e, 
as testimonies where $\dot{\eta} \gamma \varepsilon \hat{\sigma} \sigma \theta \alpha \mathrm{l} \theta \varepsilon o u ́ \varsigma$ without any trace of doubt means "to think that gods exist" ("meinen, dass Götter sind") or 'to believe that there are gods' (and see below item 3). Then there are the numerous places with double accusative or acc.cum.inf. in the sense of "think, take it, believe that someone is (a) god." All this shows that the options to believe or not to believe in gods simply were alive at least from $424 \mathrm{BC}$ onwards, and in comedy may well have been a reflexion of contemporaneous theological discussion. The term $\dot{\eta} \gamma \varepsilon \hat{\imath} \sigma \theta \alpha$ does not occur in Giordano's article.

3) One of the most remarkable utterances in the Hymn to Demetrios is: "Now, know that other gods are far away, or have no ears or don't exist or do not care about us." We also saw (Ch. VI n. 49) that Pl. Leg. 10.885b, has similar expressions concerning people who

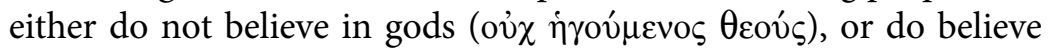
that they exist (ovv $\tau \varsigma$ ), but are regardless of mankind, while 889c-d mentions thinkers who hold that the world is governed by nature or chance and not by god. And the fourth century witnessed the birth of the very similar ideas of Epicurus on the nature of the gods.

These variant testimonies of critical reflection on both the nature and existence of gods, starting in the fifth and coming to blossom in the fourth centuries, strongly confirm that, with the exception of and as opposed to these agnostic or atheist critics, "the Greeks" did believe in the gods (unless after, say, 424 BC Greeks stopped being Greeks). The total disregard of this evidence in the paper of Giordano is incomprehensible and implies the death-blow to her theory.

Our conclusion, then, must be that while $\theta \varepsilon o$ ì $\varsigma \dot{\eta} \gamma \varepsilon \hat{\varepsilon} \sigma \theta \alpha$ is preva-

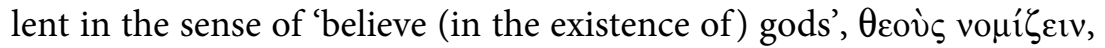
too, is frequently used in the same cognitive meaning. ${ }^{36}$ It is only at this point that we now may safely conclude that the question "did the Greeks believe in gods" is intrinsically absurd, but if for the sake of argument taken seriously (and taken in its 'low intensity' sense), should be answered in the positive.

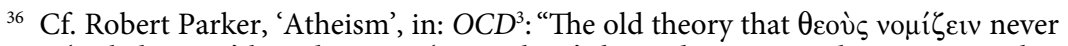
means 'to believe in' but always to 'pay cult to' the gods is wrong; but it is true that borderline cases exist." Cf. Belayche 2007, 74 f.: "Le nomizein tous theous des Grecs signifiait tout autant une opinion au sujet des dieux-croire dans les dieux-, susceptible de débat intellectuel ou d'introspection inquiète, que le pratique religieuse conforme à la tradition par nature normative-honorer les dieux-."
} 